\title{
1970-luvun tyttökansalainen, peruskoulu ja media
}

\author{
$y$ \\ 1970-luvun tytöt kasvoivat arvo- ja asenneristiriitojen \\ keskellä. Yhtäältä niin koulu kuin mediakin \\ kannustivat tyttöjä kehittämään itseään ja toimimaan \\ yksilöinä. Toisaalta heidän tuli pyrkiä ymmärtämään \\ yhteiskuntaa ja hoivaamaan muita.
}

$\boldsymbol{y}$

KEHYSKERTOMUKSEMME SARI aloitti koulunkäyntinsä peruskoulussa syksyllä 1972, suunnilleen samoihin aikoihin kuin tämän artikkelin kirjoittajat. Peruskoulua ennakoiva koulukokeilu alkoi jo vuonna 1960 kolmella paikkakunnalla. Peruskouluun siirryttiin 1970-luvulla asteittain eri puolilla Suomea (POPS I 1970, 17). 1970-luvun peruskoulun tehtäväksi tuli oppilaiden ohjaaminen omakohtaiseen tiedonhankintaan, jonka tuli olla "tehokasta ja kestävää" (emt., 14). Yhteiskunnallisessa ajattelussa ja keskustelussa korostettiin demokratiaa ja tasa-arvoa. Peruskoulua suunnittelemassa oli kasvatustieteen asiantuntijoita, jotka jakoivat 1970-lukulaisittain ajanmukaisen tasa-arvokäsityksen (Lappalainen 1985).

Peruskoulu pyrki vahvistamaan ajatusta siitä, että koulutus kuuluu kaikille sukupuoleen, luokka-asemaan ja asuinpaikkaan katsomatta (Lahelma 2014, 181). Pyrkimys kuvastaa 70-lukulaista uskoa siihen, että koulutus tuottaa sivistystä, hyvinvointia ja tasaarvoa (Sipilä \& Anttonen 2010, 44-45; Uusikylä 2006, 13). Oppilaat haluttiin kasvattaa yhteistyötaitoisiksi, humaaneiksi ja toisten ihmisten oikeuksia kunnioittaviksi kansalaisiksi (Uusikylä 2006, 14). Koululaisten uskottiin kehittyvän hyviksi kansalaisiksi peruskoulussa ja arkisissa harrastuksissa. 
Liberaalin tasa-arvokäsityksen laajenemisesta huolimatta peruskoulussa kuitenkin säilyi konservatiivisia kerrostumia (Kalalahti \& Varjo 2012, 44), mikä on keskeinen lähtökohta tälle artikkelille. Koululaisten kasvatuksessa korostettiin erilaisten yksilöiden välistä tasa-arvoisuutta, mutta samalla eri sukupuolille asetetut odotukset pysyivät monelta osin ennallaan.

1970-luku oli suurien ja nopeiden yhteiskunnallisten muutosten aikaa. Samaan aikaan kehittyvä ja kasvava media toi muuttuvan maailman kaikkien ulottuville. 1970-luvun yhteiskunnallisista muutoksista on paljon tietoa, mutta me emme tiedä paljonkaan siitä, millaisessa arvoilmastossa ja kokemusmaailmassa suuren murroksen ajan koululaiset varttuivat. Tässä artikkelissa tutkimme, millaiseen kansalaisuuteen tyttöjä 1970-luvun Suomessa kasvatettiin ja millaisia arvoristiriitoja kansalaisuuteen kasvattaminen sisälsi.

\section{AINEISTO JA MENETELMÄT}

Artikkelin idea ja näkökulma syntyivät ryhmäkeskustelun pohjalta. Ryhmäkeskustelu toteutettiin joulukuussa 2015 ja siihen osallistuivat tämän artikkelin kirjoittajat. Kirjoittajista kaksi asui ja kävi peruskoulua 1970-luvulla kaupungissa ja yksi maaseudulla. Keskustelimme 1970-luvun peruskouluun ja tyttöyteen liittyvistä muistoistamme puolentoista tunnin ajan. Keskustelun teemoina olivat peruskoulu, tasa-arvo, tyttöys, sivistys ja moraali. Ideana oli, että mahdollisesti aiemmin piiloon jääneitä teemoja saattaa tulla keskustelun aikana esiin. Peruskoulun lisäksi keskustelussamme ja muistoissamme korostuikin television ja yllättäen radion nuortenohjelmien merkitys osana 1970-luvun tyttöjen arkea ja maailman tiedostamista.

Ryhmäkeskustelua ei käytetä tässä artikkelissa analysoitavana aineistona, mutta se suuntasi aineistojen valintaamme ja analyysiamme. Keskustelun tuloksena ensisijaisiksi aineistoiksi valikoituivat Yleisradion (Yle) elävän arkiston dokumentit ja peruskoulun opetussuunnitelmaa koskevia aineistoja. Ylen elävän arkiston dokumentti- ja ajankohtaisohjelmista aineistoon valittiin viisi ohjelmaa: Mari menee balettikouluun (1976), Mikähän sinustakin tulee (1971), Erja 18 vuotta (1972), Kevätjuhlaa ja haastatteluja (1974) sekä Lukio päättyy, entä sitten? (1988). Ylen elävästä arkistosta etsittiin aineistoa hakusanoilla "peruskoulu", "1970-luku" ja "tytöt". Katsoimme viisitoista dokumenttia ja ajankohtaisohjelmaa, joista valitsimme analyysiin viisi edellä mainittua.

Peruskoulu on tyttökansalaisuuden tarkastelun kehys. Valitsimme peruskoulua käsittelevistä dokumenteista aineistoksi peruskoulun opetussuunnitelmakomitean kaksiosaisen mietinnön. Mietinnöstä rajattiin aineistoksi peruskoulun opetusta koskevia tavoitteita (POPS I 1970, 13-42) ja kansalaistaito -nimistä oppiainetta käsittelevät osuudet (POPS II 1970, 170-185). Mietintö on pedagoginen asiakirja (Uusikylä 2006, 13) ja se tuo esiin peruskoulun keskeiset valtakunnalliset tavoitteet ja arvot. Analyysissä keskitymme kansalaistaito-oppiaineeseen, sillä sitä koskevissa tavoitteissa ja oppiaineen sisällön kuvauksissa tulevat esiin hyvän kansalaisen ihanteet.

Valitsimme aineistoon myös Ylessä 1970-luvulla esitetyn Anneli Tempakan ohjelmasarjan (YLE 1978) ja ohjelmien pohjalta tehdyn kirjan Olen erilainen nuori (Tempakka 1981). Päädyimme valitsemaan aineistoksi Tempakan ohjelman, sillä se oli ensimmäinen nuorille suunnattu keskusteluohjelma. Lisäksi me kaikki muistimme ohjelman hyvin: sen äänimaiseman, ajassa vallinneiden hiljaisuuksien sanoittamisen ja ristiriitaisuuden.

Analyysimme eteni aineistojen lukemisen, televisio- ja radiodokumenttien katselemisen ja kuuntelemisen sekä ryhmäkeskustelun välisinä vuoropuheluina. Aineistoista etsittiin ja analysoitiin, miten sukupuoli ilmenee niissä ja millaisia vaateita tytöille asetettiin. Analyysissamme etsimme vastausta kysymykseen, millainen on "hyvä tyttökansalainen".

Ylen elävän arkiston dokumenteista analysoimme sitä, millaisiin käsitteellisiin kategorioihin ja kuvallisiin esityksiin tytöt liitetään ja toisaalta sitä, millaisissa yhteyksissä he ovat poissaolevia toimijoita. Peruskoulun opetussuunnitelmakomitean kaksiosaisen mietinnön peruskoulun opetusta koskevista tavoitteista ja kansalaistaito-oppiainetta käsittelevistä osuuksista analysoimme "hyvän tyttökansalaisen" esiintymistä. Tavoitteena oli selvittää, millaisena peruskoulua käyvä hyvä tyttökansalainen esitetään. Analyysin avainkysymyksenä oli, miten hyvä tyttökansalainen toimii suhteessa toisiin ihmisiin ja it- 
seensä. Aineistoa lukiessamme kiinnitimme huomiota myös siihen, miten mietinnössä esitetään hyvän tyttökansalaisen toiminnan ideaalit eli kuinka hänen tulisi toimia elinympäristössään, esimerkiksi liikkuessaan luonnossa tai liikenteessä.

Olen erilainen nuori -ohjelmasarjasta etsimme myös toiminnan ideaaleja, jotka kuitenkin asettuivat peruskoulun lisäksi ajan mediajulkisuuteen. Ohjelman sisältämät ristiriitaiset arvomaailmat antavat perspektiiviä peruskoulun arvoristiriitoihin ja kuvaavat kokonaisuudessaan yhteiskunnallisen murrosvaiheen luonnetta.

Muistelua käytimme menetelmänä, joka herätti sekä omia että jaettuja muistoja ja toi esiin olennaisia asioita 1970-luvun arvomaailmasta. Ryhmäkeskustelussa toimme esiin, mitä jo tiesimme ja toisaalta mitä halusimme selvittää tarkemmin (vrt. Palmu 2003, 8). Tv-dokumenttien katsominen mahdollisti muistelutietomme "nähdyksi tulemisen" ja liittämisen osaksi suomalaisen yhteiskunnan sosiaalista historiaa (Bell 2013). Loimme yhteisen tietovarannon ja menneisyyttä nykyisyyden kautta avaavan näköalan, kun katsoimme tv-dokumentteja, kuuntelimme Tempakan ohjelmaa ja muistelimme yhdessä 1970-lukua. Yksityisistä muistoista ja 1970-lukuun liittämistämme kokemuksista tuli dialogisen prosessin kautta sosiaalista, yhteisesti jaettua muistelutietoa (vrt. Helsti 2005, 149).

\section{0-LUKU: YHTEISKUNNALLINEN MURROS JA PERUSKOULU}

Minna Sarantola-Weiss (2008) toteaa kirjassaan Reilusti ruskeaa. 1970-luvun arki, että 1950-luvusta voidaan kertoa sodan jälkeisen jälleenrakennuksen ja modernin arkkitehtuurin ja muotoilun voittokulun tarina. 1960-luvun kertomus on radikalismin ja modernin läpimurron tarina. 1970-luku on sirpaleinen, eikä siitä ole yhtä helposti luotavissa yhtenäistä tarinaa. Antti Häkkinen $(2014,39)$ onkin kuvannut 1970-lukulaista yhteiskuntakokemusta jakaantuneeksi yksilöllisyydeksi tai yhteisölliseksi yksityisyydeksi.

Sari kasvoi varhaislapsuutensa 1960-1970-luvuilla globalisoituvassa kulttuurissa, jossa media alkoi yhä intensiivisemmin raportoida eri puolilla maapalloa tapahtuneista sodista ja ympäristötuhoista. Kuvastot nälkää näkevistä lapsista herättivät tunteita ja edesauttoivat yhteiskunnallisten liikkeiden syntyä sekä loivat myös Sarille laajaa tietoisuutta yhteisestä maapallosta ja sen ongelmista. Sanomalehdistö ja radio olivat kyenneet tarjoamaan voimakkaita kokemuksia jo aiemmin, mutta television välittämät kuvastot koskettivat ihmisiä vielä radio-ohjelmia ja lehtiuutisia vahvemmin. (Seppänen \& Väliverronen 2012,28 .) Kuvat nälkää näkevistä ja sodan kauhuista kärsivistä lapsista muodostivat katsojan ja kuvien lasten välisen suhteen (Seppänen 2001, 210).

Kehitysmaat ja ympäristötietoisuus kuuluivat 1970-luvulta lähtien yleissivistykseen, samoin kuin ihmisoikeudet ja eläinten oikeudet. 1970-luvulla syntyi Sarin mielessä entistä vahvempi tietoisuus siitä, että Suomi oli osa maailmaa ja jokainen oli omalta osaltaan vastuussa sen ongelmista. Peruskoulussa Sarin opiskelema ympäristöoppi ja kansalaistaito sisälsivät vahvan globaalin vastuun elementin.

Peruskoulun opetussuunnitelmassa vuonna 1970 sanottiin seuraavaa:

"Oppilasta tulee auttaa saatujen tietojen, taitojen ja toimintavalmiuksien pohjalta hyväksymään itsensä ja asennoitumaan elinympäristöönsä aktiivisesti, joustavasti ja luovasti, niin että hän pystyy alati muuttuvassa ristiriitojen todellisuudessa löytämään itseä ja yhteisöä rakentavia ratkaisuja." (POPS II 1970, 170.)

Demokratian ja tasa-arvon ulottuvuudet olivat jo läsnä yhteiskunnallisessa ajattelussa, politiikassa ja arjessa. 1970-luvulla ne saatettiin osiksi instituutioita. Peruskoulu-uudistus on yksi esimerkki uuden ajan järjestelmästä. Vanhempien valta väheni suhteessa lasten koulun valintaan, kun kaikki lapset tulivat peruskouluopetuksen piiriin (Okkonen 2012, 28). Tasa-arvon tavoitetta pyrittiin toteuttamaan sijoittamalla kaikki yhteen ikäluokkaan kuuluvat samaan kouluun ja luokkaan.

Suomalainen yhteiskunta kaupungistui ja muuttui teolliseksi palveluyhteiskunnaksi hyvin nopeassa tahdissa. Koska koulu ei ole yhteiskunnasta irrallinen instituutio, tuli sen uudistaminen ajankohtaiseksi. Yhteiskunnan muutos ravisutti perheitä ja asetti uusia haasteita kasvatukselle. Sarikin perheineen muutti maaseudulta kaupunkiin vanhempien töiden perässä vuonna 1972. Sarin perhe kuului työväenluokkaan. Sa- 
rin isä työskenteli rakennuksilla kirvesmiehenä ja äiti myyjänä ruokakaupassa. Peruskoulun oppilaat olivatkin taustoiltaan moninaisia ja koulun piiriin tuli myös oppilasryhmiä, jotka olivat aiemmin olleet kansa- ja oppikoulun ulkopuolella (Kirjavainen ym. 2013, 3).

Peruskoulun myötä oltiin menossa kohti globaalia kansalaisuutta sen tuodessa esimerkiksi vieraat kielet kaikkien ulottuville. Peruskoulussa opetettiin alusta lähtien sekä toista kotimaista kieltä että yhtä vierasta kieltä. Muutokseen oli tosin varauduttu jo 1960-luvulla aloittamalla vieraan kielen opetus kansakoulussa. (Hoikkala \& Paju 2008.) Tärkeää oli tietoisuus paitsi kansasta, myös siitä, että kansalainen pystyy antamaan panoksensa kansainväliseen yhteistyöhön. Oppilaassa tuli kehittää "tietoisuutta maapallon kaikkien kansojen yhteenkuuluvuudesta" (POPS I 1970, 40). Toisaalta opetuksen suunnittelussa huomioitiin maailman ja elämän ristiriidat: "Koulun olisi ohjattava oppilaita näkemään sosiaalisen elämän ristiritojen todellisuus, opetettava elämään ristiriitojen yhteisössä ja löytämään niille rakentavia ratkaisuja” (emt., 40).

Opetussuunnitelmassa (POPS I 1970, 37) korostettiin kansalaisuuden eettisiä ja moraalisia periaatteita sekä velvollisuutta, vastuuta ja omatuntoa. Koulun tuli ohjata oppilaita havaitsemaan, että "jokaisella yksilöllä on ihmisarvo, joka on riippumaton ammatista, varallisuudesta, iästä, saavutuksista, terveydestä, kyvyistä ja muista henkilökohtaisista ominaisuuksista" (emt., 39).

Opetussuunnitelmassa esitetyt tavoitteet ovat yksilön arvoa korostavia ja toisaalta yhteiskunnalliseen tasa-arvoon ja demokratiaan suuntaavia. 1970-luvun peruskoululaisille opetettiin, kuinka tärkeitä ominaisuuksia olivat hienotunteisuus, kohteliaisuus, empaattisuus, huolellisuus, ahkeruus, palvelualttius sekä mielen ja ruumiin hallinta. Tärkeinä pidettyjä ominaisuuksia olivat kurinalainen käytös ja kontrolloitu tapa suhtautua itseensä ja muihin kanssaihmisiin.

Vaikka opetussuunnitelmassa korostuvat arvot ja ominaisuudet olivat naiseuteen liitettyjä (Palmu 2003, 45), peruskoulun opetussuunnitelmassa sukupuolta ei yleensä erikseen mainita (POPS I 1970). Peruskoulu ei kuitenkaan ole sukupuolineutraali, kuten ei ole yhteiskuntakaan. Tämä heijastuu selkeästi 1970-luvun ja 1980-luvunkin nuorten ajatuksissa ja asenteissa sekä kirjoittajien omissa muistoissa.

\section{KANSALAISTAIDOT HYVÄN TYTTÖKANSALAISUUDEN PERUSTANA}

Kansalaistaito tuli oppiaineeksi kouluihin vuonna 1967. Vastaavia opetussisältöjä oli ollut aiemminkin, mutta 1960-luvulla tämän tyyppiselle oppiaineelle nähtiin erityinen tarve. Kansalaistaidossa yksilöä haluttiin kasvattaa aktiiviseksi ja toimivaksi kansalaiseksi. 1940- ja 1950 -luvuilla tavoitteena oli ollut maanpuolustuskelpoisen ja isänmaallisen kansalaisen kasvattaminen. 1960-luvulla tavoitteeksi tuli teknistyvässä yhteiskunnassa selviävä yksilö, jonka vastuu ulottui kotia ja isänmaata laajemmalle: koko maapallon ihmisiin ja ympäristöön. (Kosunen 2010.)

Kansalaistaito on 1970-luvun opetussuunnitelmassa kuvausta siitä, millainen ihminen on biologisena olentona, luonnossa ja fyysisesti rakennetussa ympäristössä elävänä kansalaisena, tietoisesti tahtovana ja tavoitteellisena ihmisenä tai toisaalta itsehillintää tarvitsevana ihmisenä. Kansalaistaidon tarkoituksena oli auttaa oppilasta "erittelemään havaintojaan ja kokemuksiaan jakamalla hänelle lähinnä kokemusperäistä, käytännöllistä tietoa elinympäristöstä, sen asettamista vaatimuksista ja tarjoamista eduista" (POPS II 1970, 170). Kansalaistaito auttoi oppilasta saatujen tietojen, taitojen ja toimintavalmiuksien pohjalta hyväksymään itsensä ja asennoitumaan elinympäristöönsä aktiivisesti, joustavasti ja luovasti. Esimerkiksi kansalaistaidon opetukseen television esitetään sopivan hyvin, koska se voi edistää "tarkoituksenmukaisiksi havaittujen käyttäytymismallien omaksumista" (POPS II 1970, 184).

Kansalaistaidon ydinsisältöjä olivat: millainen hyvä kansalainen on yhteisön jäsenenä, millaisissa sosiaalisissa rooleissa toimitaan, millaisia velvollisuuksia ja vastuita kansalaisella on. Kansalaistaidoissa oli kyse hyväksytyistä käyttäytymismalleista, jotka koskevat peruskoululaisen suhdetta itseen ja muihin ihmisiin. Mielen hallintaa pidettiin kansalaistaidon keskeisenä osa-alueena, johon sisällytettiin tunteita, järjen käyttöä ja tiedostamista (POPS II 1970, 172).

Mielen hallintaan liittyi myös järkevä ruumiin hallinta. Kehyskertomuksemme Sari kävi - koulussa ahkeroimisen lisäksi - balettikoulussa, ei niinkään ammattitanssijan urasta haaveillen, vaan siksi että se oli tytölle sopiva, fyysisiä ja henkisiäkin ominaisuuk- 
sia kehittävä harrastus. Tämä tulee esille Ylen dokumentista, jossa esitetään balettiharrastuksen kasvattavan luonnetta ja kurinalaisuutta. Balettitunnilla kehon tuntemus sekä hallinta paranevat ja opitaan kulkemaan ryhdikkäästi ja viehkeästi. Kaikki nämä ovat tytölle toivottavia ominaisuuksia. (YLE 1976.)

Hienotunteisuus, kohteliaisuus ja toisten huomioon ottaminen olivat koulussa hyveitä, jotka ovat asenteina suotavia ja mahdollistavat joustavan ja onnellisen yhteiselämän (POPS II 1970, 171). Kansalaistaitojen oppimista tuki muun muassa Raittiuskasvatusliiton teemaviikko, jonka aikana Sari oppi suojelemaan luontoa, auttamaan lähimmäisiään ja välttämään asioita, jotka voivat vahingoittaa itseä (Raittiuskasvatusliitto 1971). Heikommassa asemassa olevien lähimmäisten huomioiminen sekä erityisesti vanhuksiin kohdistuvan ystävällisyyden ja avuliaisuuden vaatimukset vetosivat Sariin.

Tavoiteltavina käytöstapoina opetusohjelmissa esitetään, että oppilaan tulee oivaltaa, että emme elä yksinomaan itseämme varten. 1970-luvun dokumenttifilmeissä tulevat esiin samat ihanteet: tyttöjen, kuten Sarinkin, odotetaan pitävän huolta nuoremmista sisaruksista, tekevän kotitöitä ja kaikin tavoin ottavan muut ihmiset ja heidän tarpeensa huomioon (YLE 1972). Nämä arvot ja ominaisuudet heijastuvat myös 1970-luvun tyttöjen ammattihaaveissa. Dokumenteissa esiintyvät tytöt suunnittelevat opiskelevansa kodinhoitajaksi, psykologiksi, käsityönopettajaksi tai muihin palveluammatteihin, kuten parturi-kampaajaksi. Sarikin päättää hankkia ammatin, jonka avulla hän voi auttaa muita ja päätyy lukion jälkeen 1980luvulla opiskelemaan sairaanhoitajaksi monen tyttöystävänsä ja ikätoverinsa lailla.

Avuliaisuuden ja empaattisuuden ohella tytöiltä odotetaan itsenäisyyttä, yksilöllisyyttä ja pärjäämistä. 1970-luvun tytöille painotetaan itsenäisyyden merkitystä. Vuonna 1972 Erja, 18-vuotias "keskivertonuori", kuvailee, kuinka hänet on kasvatettu työtä pelkäämättömäksi ja itsenäiseksi. Hän on 11-vuotiaasta asti ollut kesätöissä eikä hän ole nirso töiden suhteen. (YLE 1972.)

Enemmistö suomalaisista naisista on aina tehnyt työtä ja toisen maailmansodan jälkeen enenevässä määrin palkkatyötä (Oinonen 2004, 78-85). Suomalaisen yhteiskunnan nopean modernisoitumisen ja rakenteel-
AvuliaisuUden JA

EMPAATTISUUDEN OHELLA

TYTÖILT $\ddot{A}$ ODOTETAAN

ITSEN $\ddot{A} I S Y Y T T \ddot{A}$,

YKSILÖLLISYYTT $\ddot{A}$

JA P $\ddot{A} R J \ddot{A} \ddot{A M I S T} \ddot{A}$.

lisen muuttumisen myötä 1960- ja 1970-luvuilla tyttöjen odotettiin opiskelevan, hankkivan oman ammatin ja tekevän työtä. Nämä odotukset tulevat selkeästi esiin dokumenttifilmeissä. (YLE 1972; 1974; 1988.) Koulutuksen ja oman ammatin kautta saavutetaan taloudellinen itsenäisyys, riippumattomuus, vapaus ja oma, yksilöllinen identiteetti (POPS II 1970, 177).

Oikeastaan Sari oli haaveillut ryhtyvänsä lääkäriksi eikä sairaanhoitajaksi, mutta niin monen ikäisensä tytön tavoin hän ei lukion päättyessä oikein usko itseensä ja mahdollisuuksiinsa. Kevätjuhlaa ja haastatteluja- sekä Lukio päättyy, entä sitten? -dokumenteissa (YLE 1974; 1988) hyvin koulussa päränneet tytöt eivät puhu tulevaisuudestaan samanlaisella määrätietoisuudella kuin pojat. Kielilinjalta laudaturin paperit vuonna 1974 kirjoittanut tyttö uskoo jatkokoulutusmahdollisuuksiensa olevan kovin rajalliset muuhun kuin kielten opiskeluun. Hän kyllä tähtää psykologian opintoihin, mutta toteaa naispsykologien olevan työmarkkinoilla hyvin huonossa asemassa. (YLE 1974.)

Lukio päättyy, entä sitten? -dokumentissa vuodelta 1988 haastateltavana on kaksi abiturienttipoikaa ja tyttö. Pojilla on selvä suunnitelma siitä, mihin he menevät opiskelemaan sekä varasuunnitelma sen varalle, ettei ensisijainen tavoite toteudu. Haastatellulla tytöllä ei ole selkeää suunnitelmaa. Hän sanoo ajatelleensa kauppakorkeakoulua, "jos ei muuta keksi", vaikkei hänellä kaupalliselle alalle "mitään erityistä paloa olekaan”. Tavoitteeksi nousee akateemisen ammatin saaminen, sillä hän uskoo töiden olevan mielekkäämpiä ja palkan parempi kuin ammatillisen koulutuksen saaneilla. (YLE 1988.) Kuten reilu kymmenen vuotta aikaisemminkin, tytöt vaikuttavat aineiston valossa epävarmemmilta tulevaisuuden suunnitelmiensa 
suhteen kuin pojat. Tyttöjen puheista päätellen: tytöt eivät mene minne haluavat, vaan minne pääsevät.

\section{MEDIA-ARKI JA TYTTÖKANSALAISUUS}

Ajan mediakulttuuri alkoi tuoda Sarin elämään uusia tapoja hahmottaa ja ymmärtää maailmaa ja sosiaalisia suhteita. Radion ja television ohjelmatarjonta laajeni ja monipuolistui ja samaa tahtia kasvoi myös katsojakunta: syksyllä 1969 lunastettuja televisiolupia oli jo miljoona (Kortti 2007). Sari katseli ajan suosittuja tv-sarjoja: Peyton Placea, Heikki ja Kaija -sarjaa sekä Naapurilähiötä, jotka nostivat esiin tunteet, ihmisten väliset suhteet ja seksuaalisuuden.

Avoin ihmissuhteista ja tunteista puhuminen tai niiden käsittely julkisuudessa oli ollut tähän saakka harvinaista. Arkipäivän mediaa hallitsi valistava ja faktaperustainen tiedonvälitys. Uudentyyppiset julkisuuden muodot olivat kuitenkin hiljalleen astuneet esille jo 1960-luvulla. Tutkijat (Saarenmaa 2010; Jallinoja 1987) ovat nimenneet tämän prosessin julkisuuden intimisoitumiseksi. Aluksi intimisoituminen tuli näkyviin julkisuuden henkilöiden yksityiselämän tapahtumien kuvaamisena esimerkiksi lehdistössä ja myöhemmin juuri ulkomaisten ja kotimaisten dramatisoitujen perhesarjojen suosiossa (Elfving 2008). Alkuvaiheessa sarjat herättivät paljon kritiikkiä, koska ne rikkoivat käsityksiä siitä, miten tunteista ja seksuaalisuudesta saa julkisuudessa puhua. Toisaalta keskustelua herätti se, että ohjelmien ei katsottu kuvaavan todellisuutta, esimerkiksi työläisperheen ongelmia riittävän realistisesti (Hokka 2014).

Radio oli 1970-luvulla tärkeä media suomalaisille television ohella: vuonna 1975 Suomessa oli kaksi miljoonaa radiolupaa (Salokangas 1996, 191-192). 1970-luvun tyttökansalaisuutta ei määritä vain koulu tai koti, vaan myös se mikä tuli median kautta vapaaaikaan ja yksityisen tyttökansalaisen elämänpiiriin. Jos peruskoulun opetussuunnitelma ja sen käytännön toteutus sisälsivät arvoristiriitoja, arvomaailmojen yhteentörmäys koski myös mediasisältöjä. Esimerkiksi Sarin suosikkiohjelma, Nuorten sävellahja, saattoi tavoittaa yli miljoona kuulijaa joka lauantai-iltapäivänä (YLE 2015), mutta se ei kuitenkaan täysin täyttänyt Ylen valistus- ja sivistysperiaatteita.
Ylen pääjohtajan Eino S. Revon mukaan nimetyn Reporadion toimintaperiaatteiden mukaan ohjelmien tuli olla asiallisia ja tasapuolisia sekä informatiivisia. Pyrkimys toteutti Ylen julkisen palvelun periaatetta, joka perustui ajatukseen koko kansakunnan palvelemisesta. Toisaalta taustalla oli usko yhtenäiskulttuuriin ja siihen, että tasapuolisella ja monipuolisella ohjelmapolitiikalla suomalaiset saivat tarvitsemansa tieto-, sivistys- ja ajanvietetarjonnan. (Ruohomaa 2011, 68.) Ylen rinnalla toimi mainosrahoitteinen Mainostelevisio, mutta myös sen ohjelmistossa oli piirteitä informatiivisesta ohjelmapolitiikasta, esimerkiksi kansallisen kulttuurin vaalimista pidettiin tärkeänä (Valaskivi 2002, 38-39).

Nuorten sävellahjassa soitettiin nuorten toivekappaleita - ajan kotimaista ja ulkomaista pop- ja rock-musiikkia - ja nuoret lähettivät toisilleen terveisiä ja samalla lahjoittivat rahaa hyväntekeväisyyskohteeseen. Ristiriita syntyi siitä, että vaikka ohjelmalla pyrittiin "hyvään päämäärän" lahjoittamalla rahaa hyväntekeväisyyteen ja haastamalla ikätovereita tekemään samoin, ohjelmassa soitettu, pääasiassa angloamerikkalainen populaarimusiikki ei sopinut Ylen sivistyspyrkimyksiin. Populaarimusiikin "kannattajien" ja "vastustajien" välinen kiista leimasikin julkista keskustelua 1970-luvulla (ks. Lipponen 1983).

Yleisradion nuortenohjelmien toimittaja Anneli Tempakan ohjelmasarja Olen erilainen nuori, jota lähetettiin vuosina 1978-1980 toteutti Ylen periaatteita (ks. myös Tempakka 1981). Ohjelmassa Tempakka haastatteli nuoria, joilla oli jokin vaikea sairaus tai vamma, tai jotka muuten poikkesivat ajankohdan normistosta esimerkiksi seksuaaliselta suuntautumiseltaan. Ohjelmasarjassa haastateltiin mm. diabeetikkoa, kuuroa, homoseksuaalia, änkyttävää ja nivelreumaa sairastavaa nuorta. Vastaavaa haastatteluohjelmaa ei aiemmin oltu Ylen kanavilla kuultu. Esimerkiksi homous tai lesbous ilmaistiin julkisuudessa vielä rikollisuutena ja sairautena (ks. Juvonen 2015, 166).

Sari seurasi Tempakan ohjelmaa. Erityisesti hänen mieleensä jäi jakso Ritva on lesbo (YLE 1978). Kuunnellessaan ohjelmaa Sari huomasi, kuinka Tempakka suhtautui periaatteessa myötämielisesti haastateltaviin ja antoi heille runsaasti tilaa puhua. Hän ei kuitenkaan tuonut esiin empaattisuutta haastateltavaa kohtaan, ainakaan kysymysten muotoilussa, vaan esitti kysy- 
mykset kuivakkaan asiallisesti ja suorasukaisesti: "Silloin kun olit vielä koulussa ja teillä oli voimistelutunti, niin hipelöitkö, tai siis pyritkö hipelöimään tyttökavereita?” Ennen "hipelöitkö" -sanaa Tempakka yskäisee hämillään. Haastateltava vastaa painokkaasti: "En".

Tempakka kertoo jaksossa myös siitä, kuinka hän Ritvan kutsumana käy Seta ry:n diskossa:

"Minua jännitti ennen menoa kovasti ja olipa minulla aikamoisia kauhukuviakin mielessä, runsaasti tietämättömyyttä ja ennakkoasenteita. Eräs tyttö tuli hakemaan tanssiin ja kun vastasin kieltävästi, hän iloisesti sanoi 'okei, haen sitten toista'. Jos tanssiin hakija olisi ollut mies ja ehkä vielä humalassa ja paikka tavallinen tanssipaikka, niin luulen, että olisin saanut luetella pitkän liudan valheita, miksi en. Nyt rehellinen vastaus riitti. Kaiken kaikkiaan yleisvaikutelmaksi diskosta jäi, että nuoret siellä olivat siististi pukeutuneita ihan tavallisia ihmisiä, jossa vain tanssiparin valinta kieli homoseksuaalisuudesta." (YLE 1978.)

Tempakan ohjelma voidaan tulkita merkkinä julkisuuden intimisoitumisesta 1970-luvun Suomessa, mutta lainaus tuo hyvin esiin Tempakalle ominaisen ristiriidan. Yhtäältä hän pyrkii astumaan yksityisen ja intiimin alueelle, mutta toisaalta häntä sitoi yhtenäiskulttuurin "tavallisuuden" vaatimus, jonka määreinä tässä tapauksessa ovat siisteys ja heteroseksuaalisuus. Jälkimmäistä diskossa kävijät eivät täytä, mutta Tempakan mukaan he olivat kuitenkin "siistejä". Toisin sanoen Tempakan ohjelman intiimiys suodattui informatiivisen ja valistavan ohjelmapolitiikan myötävaikutuksella.

Valistuksellisista pyrkimyksistä kertoo myös Tempakan ohjelman sijoittaminen ohjelmavirtaan: se lähetettiin joka lauantai välittömästi suositun Nuorten sävellahjan jälkeen. Tämän päivän näkökulmasta Tempakan ohjelma voidaankin tulkita valistuksellisena väliintulona populaarikulttuuria sisältävän ohjelman jälkeen. Raimo Salokangas $(1996,339)$ on todennut, kuinka 1970-luvulla populaarikulttuuri oli legitiimiä Ylessä "vain syöttinä, joka sai kuuntelijan nielaisemaan normatiivisen annoksen varsinaisesta sivistyksestä".

Myös koulun kansalaistaidon opetuksessa korostettiin heteroseksuaalisuutta, avioliittoa ja itsehillinnän välttämättömyyttä sukupuolisen käyttäytymisen alueella. Samalla painotettiin, että yksilöllä tuli olla tar- peeksi tietoja sukupuolielämän tosiasioista. Tovereilta saatuja tietoja pidettiin epäasiallisina ja väritettyinä ja joukkotiedotusvälineiden jakamaa valistusta liian ihanteellisena ja toiveikkaana." Toisaalta se taas antaa väärän kuvan esittämällä sukupuolielämän tilanteita, jopa sairaalloisuutta lähenteleviäkin, tiheämmin kuin niitä normaalissa terveessä elämässä esiintyy." (POPS II 1970, 173.) Oppilasta ohjataan tiedostamaan mahdolliset omat ristiriitansa ja elämää tuhoavat yllykkeet. Muun muassa sukupuolisuus on alue, joka voi vaatia itsehillintää (emt., 174). Peruskoululaisen tuli kasvaa aikuiseksi, joka on toisia ihmisiä kohtaan suvaitsevainen ja empaattinen. Samalla suhteessa omaan seksuaalisuuteen tavoitteena oli terve seksuaalisuus ja vahva itsekontrolli. Tätä tavoitetta vartioivat sekä koulu että media.

Anneli Tempakan ohjelma ja peruskoulu ylläpitivät yhtenäiskulttuuria, "tavallisuutta" ja perinteisiä arvoja. Tempakka ohjelmineen kuitenkin myös sanoitti ja toi Sarin ja ikätovereidensa tietoisuuteen yhteiskunnassa vallitsevaa erilaisuuden kirjoa. Intiimillä alueella ristiriita oli erityisen vahva. Suvaitsevaisuutta maailman eri kansoja kohtaan korostettiin, mutta yksityisen ihmisen intiimielämässä yhdenmukaisuuden vaatimus oli edelleen vahva. Kansalaistaidon perhekasvatukseen keskittyvässä osiossa korostetaan tyttökansalaisen tulevaa roolia vaimona ja äitinä. (POPS II 1970, 174.)

\section{RISTIRIITAINEN 1970-LUKU}

1970-luvun tytöt elivät ja kasvoivat arvo- ja asenneristiriitojen keskellä. opetussuunnitelmasta ja mediadokumenteista. Tasa-arvo ja siihen liittyvä suvaitsevaisuus olivat 1970-luvun modernin Suomen keskeiset periaatteet. Käytännössä niin peruskoulussa kuin mediassakin nämä "modernit" tavoitteet törmäsivät "traditionaalisiin" rajoituksiin. 1970-luvun peruskoulun opetussuunnitelma on muodollisesti sukupuolineutraali, mutta samalla se on erilaisten dikotomioiden ja kuvausten kautta sukupuolittunut vahvistaen siten yhteiskunnan sukupuolten välistä jakoa (Palmu 2003, 45; Lahelma 1992, 117-119).

1970-luku oli myös yksityisen ja julkisen rajankäynnin aikaa. Yksityinen pyrki tulemaan näkyväksi ja hyväksytyksi osaksi julkista elämänaluetta. Erityi- 
sesti kasvava mediatarjonta vahvisti tätä pyrkimystä. Peruskoulu kuitenkin uusinsi traditionaalisen yhteiskunnan yksityisen alueen arvomaailmaa, samalla vastuuttaen yksilöä itseään tekemään omat valintansa. Erityisesti kansalaistaito oppiaineena vahvisti perinteisiä käsityksiä yksityisestä elämänalueesta, eritoten sukupuolirooleista (vrt. Koski 1999). Kansalaistaidon opetusta koskevissa opetussuunnitelman tavoitteissa jopa korostuu pyrkimys estää moniarvoisen yksityisen elämänalueen esiintuloa, vaikka ajan periaatteiden mukaisesti sitä pitäisi suvaita. Peruskoulu tuki sukupolvesta toiseen jatkuvaa perinteistä miehen ja naisen välistä vastuunjakoa (Lahelma 1992, 38).

Peruskoulun opetussuunnitelma (1970) pyrkii tuottamaan tasa-arvoa korostamalla sitä yleisellä tasolla ja ohittamalla muun muassa sukupuolen muutamaa poikkeusta lukuun ottamatta: kansalaistaidon perhekasvatuksen sekä liikennekasvatuksen osa-alueissa sukupuolierot ja -roolit tuodaan selkeästi esiin. Myös dokumenttikuvastoissa näkyy selviä sukupuolia erottelevia tapoja olla, puhua ja esiintyä. Moderniin maailmaan sopeutumisen ja haltuunoton ohella tyttöyttä märïttävät hyvin traditionaaliset naisellisiin hyveisiin liitetyt arvot ja odotukset. "Hyvä tyttö" oli auttavainen, huomaavainen, empaattinen ja käytökseltään hillitty. Peruskoulussa opetetaan ja odotetaan tytöiltä ominaisuuksia, joita ei kuitenkaan välttämättä arvosteta (Palmu 2003, 47). Dokumenteissakin toimittajat pitävät pojat äänessä ja asettavat tytöt sievään sivurooliin lukuun ottamatta Erja 18 vuotta -dokumenttia, joka keskittyy täysin keskivertonuorta edustavaan Erjaan ja hänen ajatuksiinsa. Tämä vanhojen vaatimusten ja uusien odotusten välissä kasvaminen osaltaan selittää abiturientti- ja ylioppilastyttöjen haastatteluista nousevaa epävarmuutta.

Tytöt näyttäytyvät dokumenttiaineistossa eteenpäin menevinä ja muutosmyönteisinä. He ovat halukkaita kehittämään itseään ja tekemään töitä sen eteen, että sopeutuvat ja osaavat vastata kovaa vauhtia modernisoituvan yhteiskunnan vaateisiin. Tästä hyvänä esimerkkinä on asutustilan tytär. Hän - toisin kuin veljensä, jotka ovat kansakoulun jälkeen isänsä lailla päätyneet metsätöihin - on käynyt keskikoulun ja on Mikähän sinustakin tulee -dokumentin kuvaamisen aikaan Ruotsissa töissä tienaamassa rahaa, jotta voi jatkaa opintojaan menemällä lukioon (YLE 1971).

Dokumenttiaineistosta välittyvä kuva 1970-luvun, erityisesti maaseudun ja kehitysalueiden eteenpäin menevistä tytöistä ja paikalleen jämähtäneistä pojista ei ole vailla todellisuuspohjaa. Opiskeluhaluiset, omaa ammattia ja itsenäisyyttä havittelevat tytöt muuttivat poikia hanakammin pohjoisesta etelään ja maaseudulta kaupunkeihin (Valkonen ym. 1980).

Naiset ovatkin olleet suomalaisen modernin hyvinvointiyhteiskunnan luomisen moottoreita. Matti Hannikaisen (2010) mukaan hyvinvointi ja tasaarvo lisääntyivät 1970-luvulla, koska julkinen sektori kasvoi työllistäen erityisesti koulutettuja naisia kasvaville hoiva- ja terveyspalvelu- sekä koulutussektoreille. 1970-luvun tyttöjä kasvatettiin suomalaista hyvinvointivaltiota rakentaviksi ja ylläpitäviksi, osaaviksi, ahkeriksi, alati itseään kehittäviksi ja muut huomioon ottaviksi naisiksi, joiden paikka on kotona, töissä ja yhteiskunnassa.

Niin 1970-luvun peruskoulussa kuin mediassakin tähdennettiin yhtäältä sitä, kuinka tärkeää on osoittaa ystävällisyyttä ja avuliaisuutta erityisesti heikompia, avun tarpeessa olevia ja vanhuksia kohtaan. Toisaalta korostettiin, kuinka arvokasta yksilön on ponnistella oman itsensä kehittämiseksi. 1970-luvulla niin peruskoulussa, mediassa kuin yhteiskunnassakin vallinneet ristiriidat ohjasivat meitä 1970-luvun tyttöjä pohtimaan, mistä näissä ristiriidoissa on kyse. Voi jopa ajatella, että ristiriitainen 1970-luku on toiminut tahattomana oppilaan ohjaajana ja saanut meidät kirjoittajat suuntautumaan yhteiskunnan ja kulttuurin tutkimuksen kentälle. Sari sen sijaan halusi auttaa heikompia toimimalla käytännössä. Hän haaveili lääkärin ammatista, mutta lukion jälkeen hän ei oikein uskonut mahdollisuuksiinsa päästä opiskelemaan lääketieteelliseen ja pyrki sen sijaan sairaanhoitajakoulutukseen.

Miten edellä pohtimamme suhteutuu nykyaikaan, mikä on muuttunut? 1970-luvun peruskoulu opetti toimimaan yhteisössä, jossa otetaan toiset huomioon. Yksilön ensisijainen tehtävä ei ollut keksittyä itseensä ja itsensä arviointiin, mitä nykyään harjoitellaan jo päiväkoti-ikäisestä lähtien. Radio-ohjelmassaan Anneli Tempakka sanoitti 1970- 
luvun lapsille ja varhaisnuorille tabuja ja hiljaisuuksia, jotka tuolloin vallitsivat vahvana suomalaisessa yhteiskunnassa. Tempakan ohjelman useimmat sisällöt eivät kuitenkaan olleet sellaisia, että niistä olisi uskallettu puhua aikuisille tai edes kavereiden kesken. Nykyisin esimerkiksi seksuaaliseen suuntautumiseen, vammaisuuteen ja ylimalkaan erilaisuuteen liittyvät tabut ovat hälventyneet ja niistä on lupa keskustella. 1970-luvulla niin koulu kuin mediakin kannustivat tyttökansalaista kehittämään itseään ja näkemään itsensä yksilönä. Samalla hänen tuli pyrkiä ymmärtämään yhteiskuntaa ja hoivaamaan muita. Vaikuttaa siltä, että tyttö- ja naiskansalaisen arvokkaina pidetyt ominaisuudet ja hänelle astutetut odotukset eivät ole sisällöllisesti juurikaan muuttuneet. Hoivatehtävien määrä on kasvanut ja naisten yhteisöltä ja yhteiskunnalta saama tuki on jatkuvasti vähenemässä.

\section{Eriikka Oinonen \\ YTT, sosiologian yliopistonlehtori \\ Tampereen yliopisto}

Tarja Rautiainen-Keskustalo

FT, musiikintutkimuksen professori

Tampereen yliopisto

\section{Tiina Tiilikka}

YTT, sosiaalialan yliopettaja

Seinäjoen ammattikorkeakoulu

\section{LÄHTEET}

Bell, S. E. (2013). Seeing narratives. Teoksessa M. Andrews, C. Squire \& M. Tamboukou (toim.) Doing Narrative Research. Los Angeles: SAGE.

Elfing, S. (2008). Taikalaatikko ja tunteiden tulkit. Televisio-ohjelmia ja -esiintyjiä koskeva kirjoittelu suomalaisissa lehdissä 1960- ja 1970-luvuilla. Tampere: Tampere University Press.

Hannikainen, M. (2010). Lapionvarresta näyttöpäätteelle. Teoksessa K. Häggman, P. Markkola, M. Kuisma \& P. Pulma (toim.) Suomalaisen arjen suuri tarina. Helsinki: WSOY, 63-83.

Helsti, H. (2005). Hedelmällisen tiedon jäljillä teemakirjoitukset tutkimuksen lähteinä. Teoksessa P. Korkiakangas, P. Olsson \& H. Ruotsala (toim.) Polkuja etnologian menetelmiin. Helsinki: Ethnos ry, 148-159. https://helda.helsinki.fi/bitstream/handle/10224/4571/ helsti148-159.pdf?sequence $=1$ (Katsottu 26.5.2016)

Hoikkala, T. \& Paju, P. (2008). Entä nuoremmat sukupolvet? Sukupolvitutkimus ja nuorisopolitiikka. Teoksessa S. Purhonen, T. Hoikkala \& J.P. Roos (toim.) Kenen sukupolveen kuulut? Suurten ikäluokkien tarina. Helsinki: Gaudeamus, 270-294.

Hokka, J. (2014). Kakkoselta kaikelle kansalle. Kuulumisen politiikka YLE TV2:n arkirealistisissa sarjoissa. Tampere: Tampere University Press.

Jallinoja, R. (1987). Mitä on naiseus? Sosiologia 24(1), 32-42.

Juvonen T. (2015). Hajoava heteroseksuaalisuus. Teoksessa M. Hyvärinen, E. Oinonen \& T. Saari (toim.) Hajoava perhe. Romaani monitieteisen tutkimuksen välineenä. Tampere: Vastapaino, 164-188.
Kalalahti, M. \& Varjo J. (2012). Tasa-arvo ja oikeudenmukaisuus perusopetukseen sijoittumisessa ja valikoitumisessa. Kasvatus \& Aika 6(1), 39-55 http://www.kasvatus-ja-aika.fi/site/?page_id $=460$ (Katsottu 26.5.2016)

Kirjavainen T., Pulkkinen J. \& Jahnukainen M. (2013). Erityisopetuksen muutostrendit perusopetuksessa 2000-luvulla. Työpaperi. Valtiontalouden tarkastusvirasto. Tuloksellisuustarkastus.

Kortti, J. (2007). Näköradiosta digiboksiin: Suomalaisen television sosiokulttuurinen historia. Helsinki: Gaudeamus.

Koski L. (1999). Hyvä tyttö ja hyvä poika. Ihanteelliset yksilöt aapisten moraalisissa kertomuksissa. Teoksessa T. Tolonen (toim.) Suomalainen koulu ja kulttuuri. Tampere: Vastapaino.

Kosunen, K. (2010). Isänmaantoivoista maailmankansalaisiksi. Terveysopin oppikirjojen ja opetussuunnitelmien sisällön muutokset ja tekstien retoriset keinot 1944-1984. Pro gradu. Itä-Suomen yliopisto.

Lahelma E. (1992). Sukupuolten eriytyminen peruskoulun opetussuunnitelmassa. Tutkimuksia 132. Helsingin yliopiston kasvatustieteen laitos. Helsinki.

Lahelma E. (2014). Troubling discourses on gender and education. Educational Research 56(2), 171-183. http://www.tandfonline.com/doi/pdf/10.1080/00131 881.2014.898913 (Katsottu 11.6.2016)

Lappalainen, A. (1985). Peruskoulun opetussuunnitelman syntyprosessi ja peruskouluopetuksen johtamisjärjestelmän muotoutuminen. Tutkimuksia 28. Helsingin yliopiston opettajankoulutuslaitos. 
Lipponen, T. (1983). Kemut eetterissä - musiikin villitsijät vastaan vallitsijat. Helsinki: Työväenmusiikki-instituutti.

Oinonen, E. (2004). Finnish and Spanish Families in Converging Europe. Studies in European Societies and Politics. Tampere: University of Tampere.

Okkonen V. (2012). Vapaan koulutuksen tukisäätiön perustaminen ja yhteiskunnallinen muutos. Kasvatus \& Aika 6(3), 25-39. http://www.kasvatus-ja-aika. fi/dokumentit/okkonen_uus_0609122153.pdf (Katsottu 26.5.2016)

Palmu T. (2003). Sukupuolen rakentuminen koulun kulttuurisissa teksteissä. Etnografia yläasteen äidinkielen oppitunneilla. Helsingin yliopiston kasvatustieteen laitoksen tutkimuksia 189. http:// ethesis.helsinki.fi/julkaisut/kas/kasva/vk/palmu/ sukupuol.pdf (Katsottu 11.6.2016)

Perusopetuslaki (1998/628). Finlex. Ajantasainen lainsäädäntö. http://www.finlex.fi/fi/laki/ ajantasa/1998/19980628 (Katsottu 26.5.2016)

Raittiuskasvatusliitto (1971). Telemikro. Raittiuskasvatusliiton teemaviikon julkaisu.

Salokangas, R. (1996). Yleisradion historia 1926-1996. Helsinki: WSOY.

Sarantola-Weiss M. (2009). Reilusti ruskeaa. 1970-luvun arkea. Helsinki: WSOY.

Sipilä, J. \& Anttonen, A. (2010). Miten hyvinvointivaltio muutti elämämme? Teoksessa K. Häggman, P. Markkola, M. Kuisma \& P. Pulma (toim.) Suomalaisen arjen suuri tarina. Helsinki: WSOY, 30-61
Oinonen E. \& Tiilikka T (2014). Hector ja katoava lapsuus 1970-luvun yhteiskunnassa -luento. Laulava yhteiskunta -opintojakso. Yhteiskunta- ja kulttuuritieteiden yksikkö. Tampereen yliopisto.

Saarenmaa, L. (2010). Intiimin äänet. Julkisuuskulttuurin muutos suomalaisissa ajanvietelehdissä 1961-1975. Tampere: Tampere University Press.

Seppänen J. (2001). Katseen voima: kohti visuaalista lukutaitoa. Tampere: Vastapaino.

Seppänen J. \& Väliverronen E. (2012). Mediayhteiskunta. Tampere: Vastapaino.

Uusikylä, K. (2006). Rakastettu ja vihattu peruskoulumme. Teoksessa K. Hämäläinen, A. Lindström ja J. Puhakka (toim.) Yhtenäisen peruskoulun menestystarina. Helsinki: Yliopistopaino, Helsinki University Press, s. 13-17.

Valaskivi, K. (2002). Liepää ja rinkeliä. Johdatus asian ja viihteen suhteeseen suomalaisessa televisiossa. Sarja B43/2002. Tampereen yliopisto: Tiedotusopin laitos.

Valkonen, T. \& Alapuro, R. \& Alestalo, M. \& Jallinoja, R. \& Sandlund, T. (1980). Suomalaiset. Yhteiskunnan rakenne teollistumisen aikana. Juva: WSOY

YLE (2015). YLE yhtiönä. YLEn vuosikymmenet. http:// yle.fi/aihe/artikkeli/2015/01/11/ylen-vuosikymmenet (Katsottu 26.5.2016)

\section{AINEISTO}

POPS I (1970). Peruskoulun opetussuunnitelmakomitean mietintö osa I. Opetussuunnitelman perusteet. Komiteanmietintö 1970: A4. Helsinki.

POPS II (1970). Peruskoulun opetussuunnitelmakomitean mietintö osa II. Oppiaineiden opetussuunnitelmat. Komiteanmietintö 1970: A5. Helsinki.

Tempakka Anneli (1981). Olen erilainen nuori. Keuruu: Otava.

YLE (1971). Mikähän sinustakin tulee? Ohjelma koulutuksen merkityksestä. (23 min.) Julkaistu 8.5.1971. (Katsottu 11.2.2016): http://yle.fi/aihe/ artikkeli/2006/09/08/mikahan-sinustakin-tulee

YLE (1972). Erja 18 vuotta. (30 min) Julkaistu 21.3.1972. (Katsottu 11.2.2016): http://yle.fi/aihe/ artikkeli/2015/12/08/keskiarvotytto-asui-maallapaiski-toita-ja-pohti-kauppakoulua

YLE (1974). Kevätjuhlaa ja haastatteluja (21 min). Julkaistu 14.6.1974 (Katsottu 22.2.2016): http://yle. fi/aihe/artikkeli/2007/06/04/joko-joutui-armas-aika
YLE (1976). Mari menee balettikouluun (22 min.). Julkaistu 11.5.1976. (Katsottu 11.2.2016): http:// yle.fi/aihe/artikkeli/2011/02/02/mari-meneebalettikouluun

YLE (1978). Ritva on lesbo. (30 min) Julkaistu 21.10.1978 (Katsottu 16.5.2016): http://yle.fi/aihe/ artikkeli/2013/07/16/ritva-lesbo

YLE (1988). Lukio päättyy, entä sitten? (21 min). Julkaistu 8..2.1988 (Katsottu 22.2.2016): http://yle.fi/aihe/ artikkeli/2007/06/04/joko-joutui-armas-aika

Katila, S. \& Meriläinen, S. (2006). Henkilökohtainen kokemus tiedon lähteenä: toimintatutkimus akateemisessa yhteisössä. Teoksessa Rolin, K. \& Kakkuri-Knuuttila, M-L. \& Henttonen, E. (toim.) Soveltava yhteiskuntatiede ja filosofia. Helsinki: Gaudeamus, 134-154.

Korvajärvi, P. (2002). Locating Gender Neutrality in Formal and Informal Aspects of Organizational Cultures. Culture and Organization 8(2), 101-115. 